\title{
Can bioenergy cropping compensate high carbon emissions from large-scale deforestation of high latitudes?
}

\author{
P. Dass ${ }^{1,2}$, C. Müller ${ }^{1}$, V. Brovkin ${ }^{3}$, and W. Cramer ${ }^{1, *}$ \\ ${ }^{1}$ Potsdam Institute for Climate Impact Research, Potsdam, Germany \\ ${ }^{2}$ International Max Planck Research School on Earth System Modelling, Hamburg, Germany \\ ${ }^{3}$ Max Planck Institute for Meteorology, Hamburg, Germany \\ * now at: Mediterranean Institute for marine and terrestrial Biodiversity and Ecology, Marseille, France
}

Correspondence to: P. Dass (dass@pik-potsdam.de)

Received: 11 January 2013 - Published in Earth Syst. Dynam. Discuss.: 20 February 2013

Revised: 27 September 2013 - Accepted: 20 October 2013 - Published: 18 November 2013

\begin{abstract}
Numerous studies have concluded that deforestation of the high latitudes result in a global cooling. This is mainly because of the increased albedo of deforested land which dominates over other biogeophysical and biogeochemical mechanisms in the energy balance. This dominance, however, may be due to an underestimation of the biogeochemical response, as carbon emissions are typically at or below the lower end of estimates. Here, we use the dynamic global vegetation model LPJmL for a better estimate of the carbon cycle under such large-scale deforestation. These studies are purely theoretical in order to understand the role of vegetation in the energy balance and the earth system. They must not be mistaken as possible mitigation options, because of the devastating effects on pristine ecosystems. For realistic assumptions of land suitability, the total emissions computed in this study are higher than that of previous studies assessing the effects of boreal deforestation. The warming due to biogeochemical effects ranges from 0.12 to $0.32{ }^{\circ} \mathrm{C}$, depending on the climate sensitivity. Using LPJmL to assess the mitigation potential of bioenergy plantations in the suitable areas of the deforested region, we find that the global biophysical bioenergy potential is $68.1 \pm 5.6 \mathrm{EJ} \mathrm{yr}^{-1}$ of primary energy at the end of the $21 \mathrm{st}$ century in the most plausible scenario. The avoided combustion of fossil fuels over the time frame of this experiment would lead to further cooling. However, since the carbon debt caused by the cumulative emissions is not repaid by the end of the 21st century, the global temperatures would increase by 0.04 to $0.11^{\circ} \mathrm{C}$. The carbon dynamics in the high
\end{abstract}

latitudes especially with respect to permafrost dynamics and long-term carbon losses, require additional attention in the role for the Earth's carbon and energy budget.

\section{Introduction}

Afforestation or reforestation is considered an effective carbon sequestration measure because of significant amounts of carbon trapped in the forest biomass. However, the carbon metrics are not the only metrics to be considered in the evaluation of the forest impact on climate. Changes in forest cover affect climate through changes in biophysical parameters such as land surface albedo, evapotranspiration, and roughness. This is because albedo of forest canopies is lower than that of other vegetation or bare soil (Alton, 2009). Particularly in boreal latitudes, this albedo difference is quite enhanced when snow is present, because snow cover is masked by trees but not by herbaceous vegetation (Bonan, 2008; Nobre et al., 2004). If the snow cover period is long enough, the biogeophysical effect due to albedo changes could overcome the biogeochemical effect due to carbon storage in forests. Studies solely investigating the biogeophysical effects of deforestation on a global scale (Bounoua et al., 2002; Brovkin et al., 2006, 2009; Matthews et al., 2003) have found a net cooling. Considering both biogeophysical as well as biogeochemical effects of landuse change, afforestation in the boreal region would increase the warming due to a decreased albedo feedback, which outweighs the 
cooling caused by carbon sequestration (Arora and Montenegro, 2011; Betts, 2000). Other numerous modeling studies agree that a net sum of biogeochemical and biogeophysical effects of deforestation of the high latitudes is a cooling (Bala et al., 2007; Bathiany et al., 2010; Claussen et al., 2001).

The dominance of the biogeophysical effect of global boreal deforestation (Bala et al., 2007; Bathiany et al., 2010) could be due to an underestimation of the biogeochemical response. Bathiany et al. (2010) found that boreal (all land north of $45^{\circ} \mathrm{N}$ ) deforestation results in an immediate global emission of $20 \mathrm{GtC}$ followed by almost no change in the global terrestrial carbon during decades and centuries after deforestation. Bala et al. (2007) estimate the total global emissions from such large-scale (all land north of $50^{\circ} \mathrm{N}$ ) deforestation to be $80 \mathrm{GtC}$. Observationally based studies have estimated the global carbon stocks of the boreal forests for vegetation to be 57 to $88 \mathrm{GtC}$ (Prentice et al., 2001) and according to estimates of 2007 the same was found to be 53.9 GtC (Pan et al., 2011). In addition, the total global carbon stocks of the other carbon pools of the boreal forests, including dead wood, litter and soil amount to $217.6 \mathrm{GtC}$ (Pan et al., 2011). Therefore, we expect the value of longterm emissions, because of the slow decomposition of the carbon of these pools, to be higher than the vegetation carbon storage.

The area of interest in this study involves all landmass north of $45^{\circ} \mathrm{N}$, which is the same as that of Bathiany et al. (2010) but fractionally more than that of Bala et al. (2007). So apart from the boreal forests, the northern part of the temperate forests is also included. As per 2007 estimates, the total living biomass for temperate forests of the Northern Hemisphere is $38.2 \mathrm{GtC}$ (Pan et al., 2011). Assuming our area of interest in this study to include approximately half of the temperate forests of the Northern Hemisphere, the total living biomass in this area would amount to $\sim 73 \mathrm{GtC}$. We assume that in the event of deforestation, all the vegetation carbon is burnt and emitted to the atmosphere immediately. Apart from this, when land is converted from any form of natural state to cropland, a substantial part of carbon which is already stored in the litter and soil is decomposed and emitted due to soil respiration. Numerous studies unequivocally show that conversion of land from forest to cropland leads to degradation of soil carbon stocks (Davidson and Ackerman, 1993; Ellert and Gregorich, 1996; Guo and Gifford, 2002; Post and Kwon, 2000). So in addition to immediate emissions there would be long-term emissions. Thus it is evident that the total carbon emissions computed in the previous boreal deforestation studies (Bala et al., 2007; Bathiany et al., 2010) are at the lower end of observationally based model estimates.

Bioenergy is a cost-effective mitigation measure, as the cost of production of bioenergy combined with CCS (carbon capture and storage) is almost half compared to that of more efficient forms of renewable energy like solar energy (Magne et al., 2010). Whereas conventional 1st generation biofuels like ethanol or biodiesel have their limitations (Crutzen et al., 2008; Fargione et al., 2008; Melillo et al., 2009; Searchinger et al., 2008), 2nd generation bioenergy technologies (lignocellulosic plant material) could be used in more extensive combination, as these plants are more tolerant against unfavorable climate and soil conditions (Adler et al., 2007; Schmer et al., 2008). However, apart from destroying landscapes and reducing biodiversity (Melillo et al., 2009), bioenergy plantations lead to considerable land use change. This causes immediate emissions due to burning of aboveground biomass, as well as long-term emissions owing to decomposition of litter and soil carbon (Houghton et al., 1983). These emissions are dependent on the type of ecosystem being disturbed. For instance, if bioenergy crop plantations are carried out in tropical rainforests or peatlands, it would cause a net 'biofuel carbon debt' by emitting significantly more $\mathrm{CO}_{2}$ than the respective crop would save (Fargione et al., 2008). Apart from the biogeochemical effect, for areas affected by seasonal snow cover, the cooling contribution of an increased albedo from herbaceous bioenergy plantations is significant (Cherubini et al., 2012a). So the net effect of bioenergy plantations on the climate would depend on the balance between the biogeophysical and biogeochemical effects.

While we are not proposing large-scale deforestation as a mitigation option, we carry out a purely academic study to make a better estimation of the carbon cycle changes under large-scale deforestation of the higher latitudes. Vegetation productivity is sensitive to conditions of the climate, atmospheric $\mathrm{CO}_{2}$ concentration $\left(\left[\mathrm{CO}_{2}\right]\right)$, and different management practices (Norby et al., 2005; Oren et al., 2001; Smith et al., 2000; Witt et al., 2000). To account for projected changes in $\left[\mathrm{CO}_{2}\right]$ and climate, and to assess the biogeochemical effects of such land use and land cover change (LULUC), we used the Dynamic Global Vegetation Model (DGVM) LPJmL (Lund-Potsdam-Jena managed Land) (Bondeau et al., 2007). Apart from computing the emissions from deforestation, we also use LPJmL to investigate whether bioenergy plantations in the deforested areas, due to avoided usage of fossil fuels, is able to compensate for the carbon losses due to this deforestation. Bathiany et al. (2010) estimated combined biogeophysical and biogeochemical effects. To estimate the pure biogeophysical effects of deforestation above $45^{\circ} \mathrm{N}$ we use MPI-Earth System Model (MPI-ESM-LR) in the CMIP5 version for pre-industrial simulation (Giorgetta et al., 2013).

\section{Model and experimental setup}

\subsection{Model description}

LPJmL is a dynamic global vegetation, hydrology and agriculture model representing both natural and managed ecosystems at the global scale and having a spatial resolution of $0.5^{\circ}$ (Bondeau et al., 2007; Sitch et al., 2003). The natural 
vegetation is represented by 9 plant functional types (PFTs), while 12 crop functional types (CFTs), represent the most important crops (Bondeau et al., 2007). LPJmL is driven by monthly fields of temperature, precipitation, cloud cover, $\left[\mathrm{CO}_{2}\right]$ and soil texture (Sitch et al., 2003). This model has been recently extended to simulate the cultivation of cellulosic energy crops on dedicated biomass plantations. The detailed description is provided by Beringer et al. (2011).

This study investigates the biogeochemical and the biogeophysical effects of high-latitude bioenergy production separately, using LPJmL and MPI-ESM respectively. Thus to harmonize the experimental setup, it has been assumed that most of the biofuel production would be in the form of herbaceous bioenergy crops and bioenergy grass as their albedo is similar to natural grass.

For every experimental simulation, a spinup simulation is carried out for 1000 years, repeating the climate and land use of the first $30 \mathrm{yr},(1901-1930)$ in order to bring the distribution of natural vegetation and carbon pools into equilibrium (Bondeau et al., 2007; Sitch et al., 2003). This is followed by a $390 \mathrm{yr}$ spinup with gradually expanding land use patterns to account for the effects of historic land use on soil carbon pools.

The Earth System model developed at the Max Planck Institute for Meteorology in Hamburg, Germany, (MPIESM) includes the atmospheric model ECHAM6 in T63 $\left(1.9^{\circ} \times 1.9^{\circ}\right)$ resolution with 47 vertical levels described by Stevens et al. (2012), the oceanic model MPI-OM at approx. $1.6^{\circ}$ resolution with 40 vertical layers (Jungclaus et al., 2006), and the land-surface model JSBACH (Raddatz et al., 2007) sharing the horizontal grid of the atmospheric model. The representation of snow cover treatment in MPI-ESM is described in details in Roesch and Roeckner (2006). This grid set-up is a low-resolution version (LR) of the model used for centennial-timescale simulations in CMIP5. A detailed description of the model and an evaluation of the model performance is given by Giorgetta et al. (2013).

\subsection{Model setup}

Climate projections differ between different GCMs primarily because of the uncertainty of parameterizations. For example, the global average temperature projection for the SRES A2 scenario has an approximately $66 \%$ probability of ranging from 2.0 to $5.4^{\circ} \mathrm{C}$, at the end of the 21 st century, relative to the end of the 20th century (Solomon et al., 2007). To account for this variability, LPJmL was driven with 21st century climate projections from an ensemble of 19 different general circulation models' (GCM) implementations of the SRES A2 scenario (Nakicenovic et al., 2000) as listed in Table 1. The climate scenarios for the individual scenarios have been prepared by calculating the anomalies relative to the 1971-2000 average for each GCM and month of the 2001-2099 period and applied to the observed 1971-2000 baseline climate. A detailed description is given in Gerten
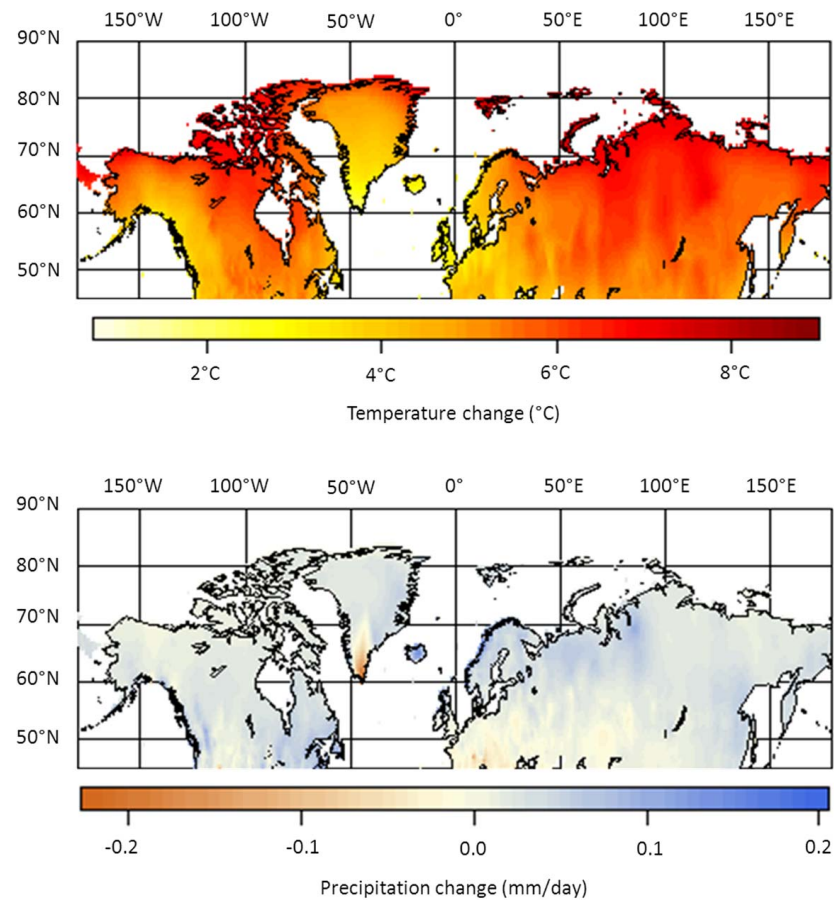

Fig. 1. (a) Temperature $\left({ }^{\circ} \mathrm{C}\right)$ and (b) precipitation $\left(\mathrm{mm} \mathrm{day}^{-1}\right)$ difference of the annual means between the end of the 21 st century and the beginning of the 20th century. The values are a mean of 19 GCMs.

et al. (2011). All these GCMs participated in the World Climate Research Program's Coupled Model Intercomparison Project phase 3 (Meehl et al., 2007) and were used in the IPCC's Fourth Assessment Report (IPCC, 2007). Figure $1 \mathrm{a}, \mathrm{b}$ demonstrates the mean annual change in temperature and precipitation, respectively, from the beginning of the 20th century to the end of the 21st century. The rise in temperature becomes more intense with increasing latitude, with temperature increases in the extreme high latitudes of more than $8^{\circ} \mathrm{C}$. This is referred to as "polar amplification" (Holland and Bitz, 2003). The precipitation change on the contrary shows a spatially heterogeneous pattern with most areas experiencing an increase while only small patches experience decreasing annual precipitation. The high variability in temperature and precipitation change patterns among the individual GCMs is illustrated in Fig. 2. The change in $\left[\mathrm{CO}_{2}\right]$ is illustrated in Fig. 3 .

\subsection{Land management scenarios}

While it could be theoretically possible to remove all natural vegetation from the high latitudes, much of the cleared land could not be directly used for bioenergy production unless specific soil and terrain restrictions are eliminated by additional management efforts. As a result we calculate the biophysical bioenergy potentials, using LPJmL for different scenarios on management efforts ranging from conservative 

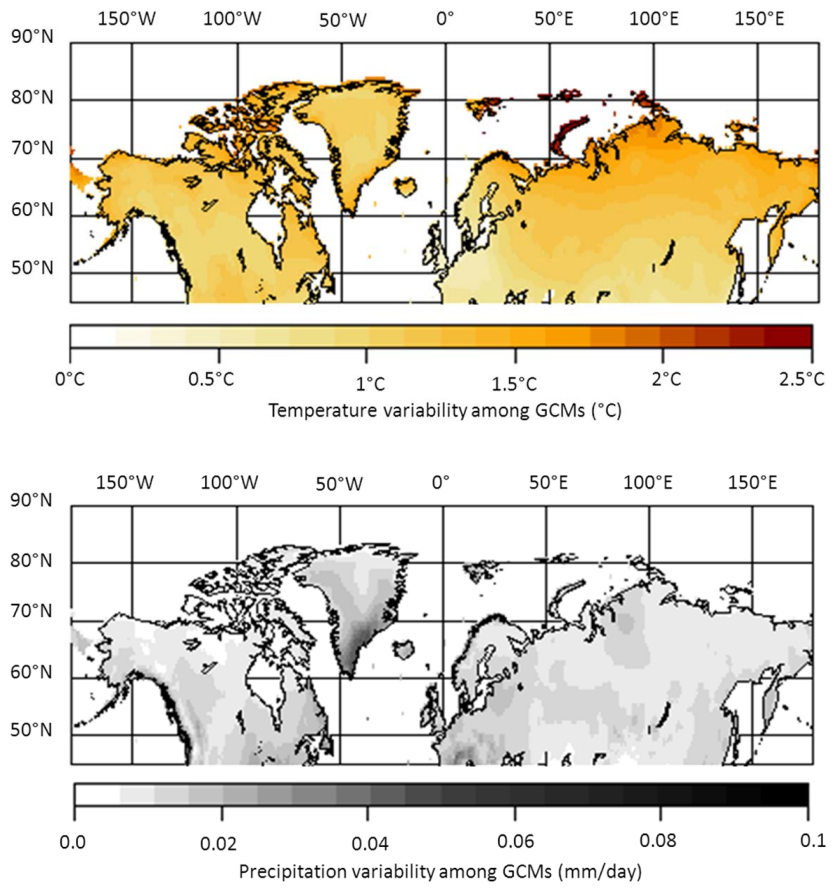

Fig. 2. The variability among the $19 \mathrm{GCMs}$ for the values of (a) temperature $\left({ }^{\circ} \mathrm{C}\right)$ and $(\mathbf{b})$ precipitation $\left(\mathrm{mm} \mathrm{day}^{-1}\right)$, plotted in Fig. 1 is demonstrated by the standard deviation.

or more plausible where all restrictions are assumed to hold (or there is no management to eliminate these) to idealistic, where no restrictions are considered (or all restrictions are assumed to be eliminated). Soil and terrain restrictions are based on the Global Agro-Ecological Zonal (GAEZ) data set (Fischer et al., 2000). The characterization of the suitability of land resources for agricultural production includes all relevant components of soils and landform, which are basic for the supply of nutrients and physical support to plants. Climatic constraints of the GAEZ data set are ignored in this study as LPJmL already uses climate data as an input and thus crop growth simulated by this model is already restricted by climate. The different land management scenarios used in this study, as tabulated in Table 4, are:

1. MAXL: land with any constraint of unsuitable terrain or unsuitable soil properties, including unsuitable soil fertility, is assumed to be unavailable for farming. Unsuitable terrain mean those areas that have severe terrain constraints (i.e. greater than $16 \%$ slope or areas with greater than slight constraints; Fischer et al., 2000). In addition we assume that land currently occupied by built area and cropland (Erb et al., 2007) is considered to be unavailable for bioenergy plantations. The remaining land is thus available for bioenergy crop plantations. As a result, we consider this to be the most plausible of all the scenarios.

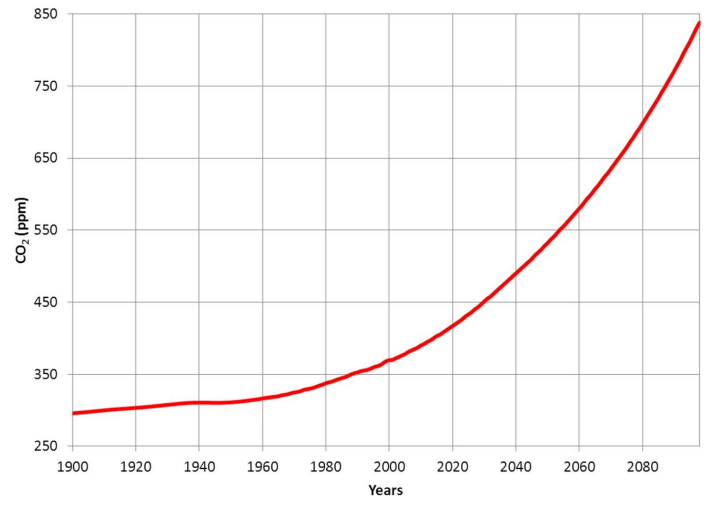

Fig. 3. Trend of $\mathrm{CO}_{2}(\mathrm{ppm})$ according to SRES A2 scenario plotted from the beginning of the 20th century to the end of the 21 st century.

2. CROPL: areas currently occupied by built area and cropland (Erb et al., 2007) in addition to "generally unsuitable soil" and unsuitable terrain are considered to be unavailable for bioenergy plantations. "Generally unsuitable soil" includes constraints of unsuitable soil depth, drainage, texture and chemistry but not soil fertility, as it is considered to be managed for example by the use of fertilizers.

3. SOILL: "generally unsuitable soil" in addition to unsuitable terrain is assumed to be unavailable to farming. Thus the remaining area is available for bioenergy crop plantations.

4. TERL: all areas are assumed to be available for bioenergy plantations except areas with unsuitable terrain.

5. UNLIM: all terrain and soil limitations are assumed to be managed, (e.g. terrain by terrace farming; soil drainage by mixing clay and sandy soil; soil structure by plough etc.). As all land area is considered to be available for bioenergy plantations, we consider this scenario to be the most idealistic.

The number of restrictions decreases in sequence of scenarios from MAXL to UNLIM and as a result the area available to bioenergy production increases (Fig. 4 and Table 4).

\subsection{Crop management}

In the LPJmL version used in this study, as described in detail by Fader et al. (2010), the management intensity, i.e. the degree of crop production control and input application (fertilizer, technology, labor, weed, and disease control, etc.) is represented by three parameters: $\mathrm{LAI}_{\max }, \mathrm{HI}_{\max }$ and $\alpha-a$, where $\mathrm{LAI}_{\max }$, which is country specific, refers to the maximal attainable leaf area index of a crop, the $\mathrm{HI}_{\max }$ refers to the maximal harvest index while the $\alpha-a$ parameter scales leaf-level biomass production to stand level. Due to the simplified treatment of agricultural management in the model, 
the management intensity values that result in the best approximation of the 1999-2003 national yields reported by FAOSTAT (2009) are used here (for details see Fader et al., 2010). Sowing dates are computed internally based on past climate experience as described by Waha et al. (2012).

\subsection{Bioenergy plantations on deforested areas}

The spatial pattern of crop production is prescribed via the historical land use data set from 1700 to 2005 as described by Fader et al. (2010) which has been extended to explicitly assign areas to the cultivation of sugarcane based on data of MIRCA2000 (Portmann et al., 2010), because sugarcane had been implemented into the model at a later stage (Lapola et al., 2009). In this study, the land use pattern of 2005 is assumed to remain constant for all the years beyond 2005 in the "CTRL" (control) simulation.

In the experimental simulations (scenarios MAXL to UNLIM), the land use remains the same as CTRL until 2010, when all land north of $45^{\circ}$ in the Northern Hemisphere is cleared of its natural vegetation. After leaving this land fallow for one year, only suitable areas (varies according to the different land management scenarios as described in Sect. 2.3) are planted with herbaceous crops (including bioenergy grass) such that those crops return maximum primary bioenergy yield $\left(\mathrm{MJ} \mathrm{ha}^{-1}\right)$. Areas unsuitable for bioenergy plantations are allowed to be naturally re-vegetated with only herbaceous vegetation. In this study LPJmL is parameterized such that on deforestation, $100 \%$ of the aboveground biomass, including $2 / 3$ of the sap wood (as it is assumed that $1 / 3$ of the sap wood is in the roots and thus belongs to the belowground carbon) is burnt and released into the atmosphere while the rest goes to the litter. The forest litter consequently enters the soil carbon pool and is then decomposed. This type of forest clearing is representative of the "slash and burn" method. This assumption of emitting all the carbon of the aboveground biomass comes from the fact that even in natural forest fires as much as $90 \%$ of the carbon at the ground layer of a severely burnt forest is consumed (Michalek et al., 2000). This assumption has also been used in earlier studies, e.g. by Grünzweig et al. (2004). For the calculation of the biophysical bioenergy potential of individual crop types, we assume that $50 \%$ of crop dry matter is carbon (Rojstaczer, 2001). The primary energy content per gram of crop dry matter is based on the Energy research Centre of the Netherlands Phyllis database (ECN, 2007) and as listed in Table 2.

The land use of the area deforested in this experiment is dynamic and depends on which crop would provide maximum energy yield for that particular year. Different crops have different temperature requirements for optimal photosynthesis as shown in Table 3 and the mix of most suitable land use types reflects the heterogeneity in climate. As an example, the land use pattern for the UNLIM scenario for the end of the 21st century is shown in Fig. 5, with the extremely unproductive regions (having yields of less than $2 \mathrm{tDM} \mathrm{ha}^{-1}$ ) masked out and the yield pattern (UNLIM scenario) is shown in Fig. 6. After annual harvest, all parts of the plant other than the storage organs are left on the field and as a result enter the litter followed by the soil carbon pool. It should be noted that for this illustration, as described in the UNLIM scenario, we allowed all land to be planted with crops, irrespective of the suitability. As a result, even the extremely high latitudes have been planted with crops but the yield in these areas is too low to significantly affect the overall biophysical bioenergy potential.

Bioenergy has been assumed to be used directly as a fuel in this study. The emissions from bioenergy usage could be thus treated as a single pulse with a short lifetime in the anthroposphere (Cherubini et al., 2012b). Thus, other than the land use emission we can consider bioenergy to be carbon neutral. In order to calculate the avoided emission, we compute the maximum biophysical bioenergy potential from non-woody bioenergy plants in the area of the high latitudes, i.e. all land north of $45^{\circ} \mathrm{N}$. By biophysical bioenergy potential, we understand the production of bioenergy for given climatic and environmental conditions, ignoring the technical and economic feasibility. In order to compare similar units we use primary energy, or the energy derived after $100 \%$ combustion efficiency, to quantify the biophysical bioenergy potential as we do not specify the form of final energy which is to be actually used (Fischer and Schrattenholzer, 2001). To calculate the emissions saved by avoided burning of fossil fuels, we again assume $100 \%$ combustion (EIA, 2008). However we do not discuss other potentially important effects of extensive bioenergy plantations.

To assess the pure biogeophysical effect of extensive deforestation, in the additional experiment with MPI-ESM, we replace all woody PFTs north of $45^{\circ} \mathrm{N}$ with grasses, keeping $\left[\mathrm{CO}_{2}\right]$ fixed at the pre-industrial value. We conduct this simulation for $30 \mathrm{yr}$.

This study uses two separate models, LPJmL to compute the biogeochemical effects, and MPI-ESM to compute the biogeophysical effects. These two models have different spatial resolutions and the simulations carried out are independent of each other. In addition, although harmonized, the experimental setups of the models are not exactly the same. Thus the biogeochemical and biogeophysical effects on the global mean near-surface air temperature are presented separately and not added together.

\section{Results}

We find that the large-scale deforestation of the area north of $45^{\circ} \mathrm{N}$ would lead to immediate C-emission of $182.3 \pm 0.7 \mathrm{GtC}$. This immediate emission would be followed by long-term changes in the litter and soil carbon pools, which range from a sequestration of $13.7 \pm 8.2 \mathrm{GtC}$ for the most plausible, MAXL scenario to an emission of $231.7 \pm 15.0 \mathrm{GtC}$ for the most idealistic scenario, UNLIM, 

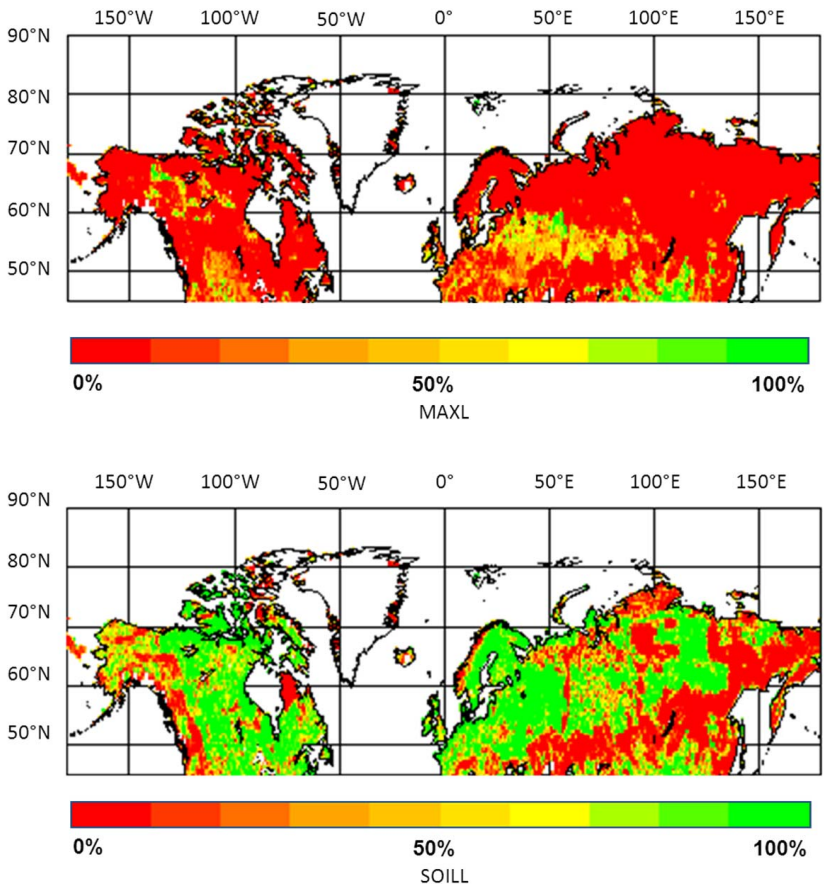
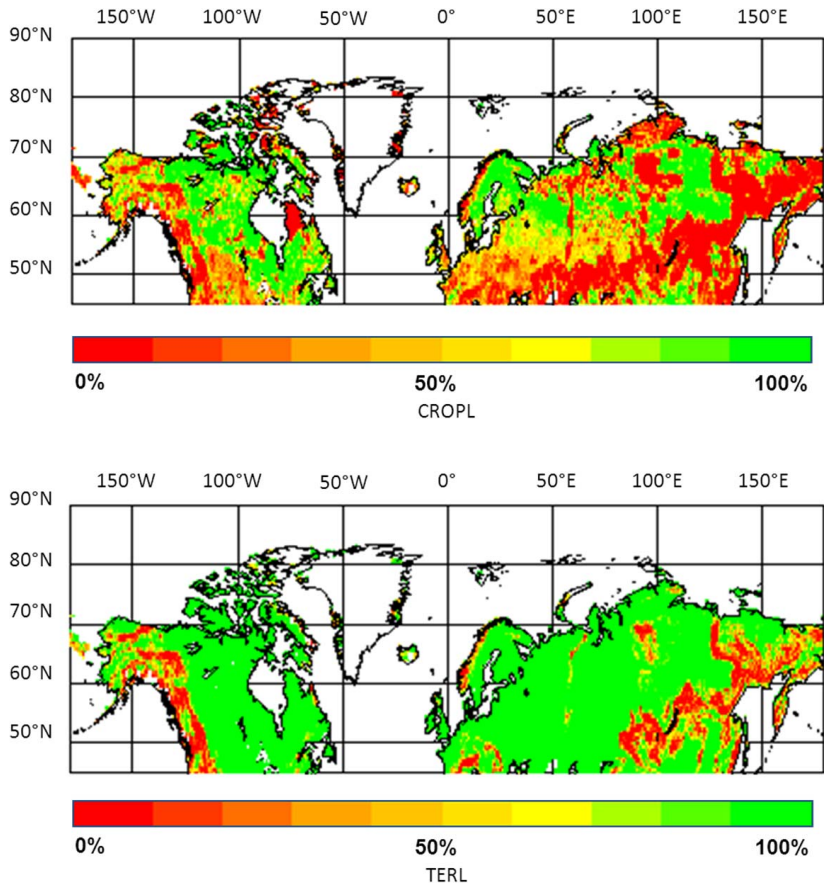

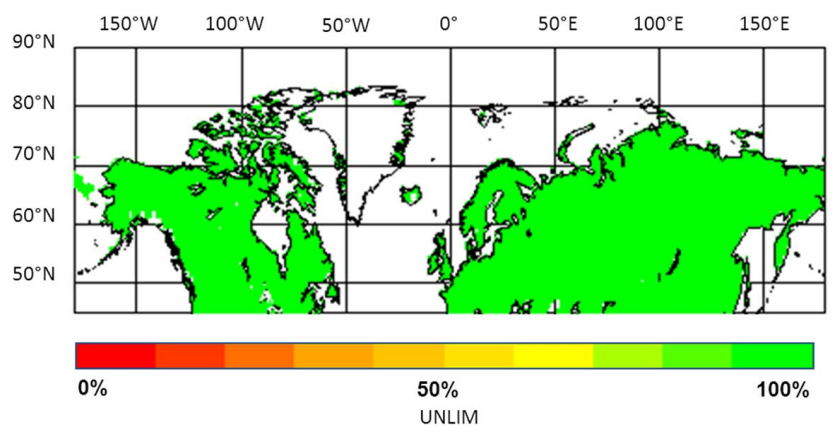

Fig. 4. Percentage of area (of each $0.5^{\circ} \times 0.5^{\circ}$ grid cell) used for bioenergy crop plantations for land management scenarios (a) MAXL, (b) CROPL, (c) SOILL, (d) TERL, (e) UNLIM. Green symbolizes complete availability while red stands for unavailability of that grid cell for bioenergy crop plantation.

by the end of the 21 st century, as shown in Table 4 and Fig. 7. The long-term emissions are dependent on the area of the land under bioenergy cultivation as the remaining land deemed unsuitable for cropping is allowed to revert to natural grasslands and thereby sequester carbon, especially in the soil and litter pools. As soil and litter pools of grasslands have more carbon compared to forests (Conant et al., 2001; Guo and Gifford, 2002), the litter and soil carbon pools of MAXL scenario is greater than the CTRL scenario. It should be noted that since LPJmL is an offline model, but MPI-ESM is run online with a prescribed $\left[\mathrm{CO}_{2}\right]$, the emissions reported above do not influence the climate forcing of the simulations.

With anthropogenic climate warming, plant productivity is expected to increase in cooler regions due to the fertilization effect of increased $\left[\mathrm{CO}_{2}\right]$ and increased temperatures metabolically enhancing photosynthesis (Melillo et al., 1993). This is reflected in the biophysical bioenergy potential which is proportional to the corresponding crop productivity, shown as a $30 \mathrm{yr}$ moving average in Fig. 8. This phenomenon is also demonstrated in Fig. 6 where the high latitude of Alaska (USA), northern Canada and parts of northern Norway and Sweden have significantly high crop yields. This is because the climate change, according to SRES A2 storyline, leads to an increase in temperature and precipitation in these areas, as demonstrated by Fig. 1. Both climate change and increasing $\left[\mathrm{CO}_{2}\right]$ lead to increasing biophysical bioenergy potentials north of $45^{\circ} \mathrm{N}$, where the climate effect is about twice as large as the effect of increasing $\left[\mathrm{CO}_{2}\right]$. In combination, the two drivers show an amplifying effect on the increase of biophysical bioenergy potentials (Fig. 8).

Biophysical bioenergy potentials of the deforested area are strongly sensitive to the different land management scenarios. With increasing land availability for bioenergy cropping, the cumulative biophysical bioenergy potential 
Table 1. The following is a list of GCMs and the corresponding sponsoring institutes whose climate projections were used in this study.

\begin{tabular}{|c|c|c|}
\hline Model no. & Model name & Sponsoring institute \\
\hline 2 & CGCM3.1 & Canadian Centre for Climate Modelling and Analysis, Canada \\
\hline 4 & CSIRO-MK3.0 & Commonwealth Scientific and Industrial Research Organisation, Atmospheric Research, Australia \\
\hline 5 & CSIRO-MK3.5 & Commonwealth Scientific and Industrial Research Organisation, Atmospheric Research, Australia \\
\hline 7 & GFDL-CM2.1 & $\begin{array}{l}\text { US Department of Commerce/National Oceanic and Atmospheric Administration (NOAA)/ } \\
\text { Geophysical Fluid Dynamics Laboratory (GFDL), USA }\end{array}$ \\
\hline 8 & GISS-ER & $\begin{array}{l}\text { National Aeronautics and Space Administration (NASA)/Goddard Institute for Space Studies } \\
\text { (GISS), USA }\end{array}$ \\
\hline 12 & MIROC3.2(M) & $\begin{array}{l}\text { Center for Climate System Research (University of Tokyo), National Institute for Environmental } \\
\text { Studies, and Frontier Research Center for Global Change (JAMSTEC), Japan }\end{array}$ \\
\hline 13 & ECHO-G & $\begin{array}{l}\text { Meteorological Institute of the University Bonn, Meteorological Research Institute } \\
\text { of the Korea Meteorological Administration (KMA), and Model and Data Group, Germany/Korea }\end{array}$ \\
\hline 14 & ECHAM5/MPI-OM & Max Planck Institute for Meteorology, Germany \\
\hline 15 & MRI-CGCM2.3.2 & Meteorological Research Institute, Japan \\
\hline 16 & CCSM3 & National Center for Atmospheric Research, USA \\
\hline 17 & PCM & National Center for Atmospheric Research, USA \\
\hline 18 & UKMO-HadCM3 & Hadley Centre for Climate Prediction and Research/Met Office, UK \\
\hline
\end{tabular}
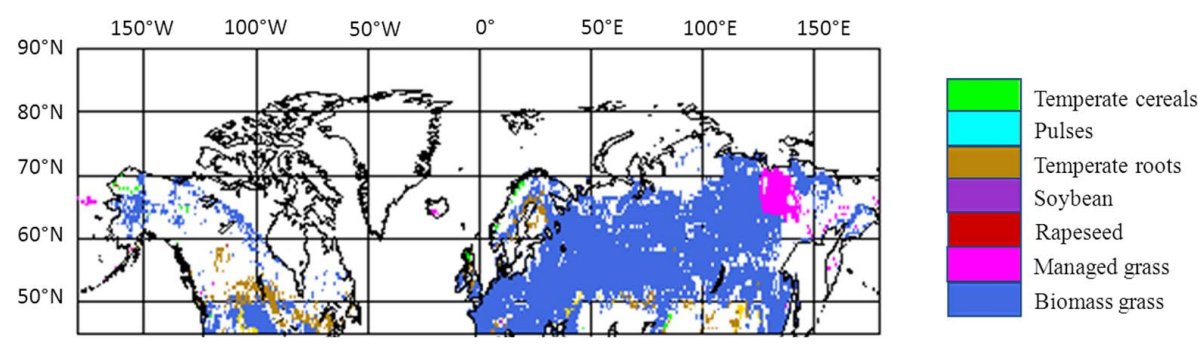

Fig. 5. The land use pattern at the end of the 21st century for the UNLIM scenario with areas having extremely low yielding areas (less than $2 \mathrm{tDM} \mathrm{ha}^{-1}$ ) masked out.

increases with decreasing constraints on land management efforts (Fig. 9). Reflecting the uncertainty in climate projections, biophysical bioenergy potentials are also sensitive to the selection of the GCM realization of the SRES A2 emission scenario. This uncertainty increases with the area assumed to be available for bioenergy production (Fig. 9). The bioenergy potentials at the end of the 21 st century, along with the uncertainty, have also been tabulated in Table 5.

Assuming $20.9 \mathrm{gC}$ to be emitted per MJ of fossil fuel burnt (an average of all stationary and transportation fuels and considering $100 \%$ combustion efficiency) (EIA, 2008), this

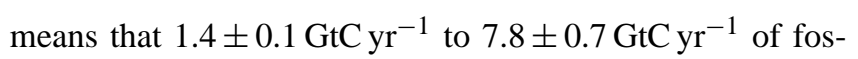
sil fuel emissions could be saved at the end of the 21 st century if the biophysical bioenergy potential would be fully exploited. Over the entire time frame of this study, bioenergy plantations could thus cumulatively save $102.2 \pm 5.1 \mathrm{GtC}$ to $569.5 \pm 36.6 \mathrm{GtC}$ (Table 5). To convert these saved emissions into avoided warming, we use a metric of transient climate sensitivity to cumulative emissions suggested by Matthews et al. (2009) and evaluated for Earth System models taking part in the climate model intercomparison project 5 (CMIP5) by Gillett et al. (2013). They concluded that the observationally 
Table 2. CFTs of LPJmL and the primary energy per CFT (ECN, 2007).

\begin{tabular}{lllc}
\hline CFT & CFT name & Examples & $\begin{array}{c}\text { Energy in kiloJoules } \\
\text { per gDM (Phyllis HHV) }\end{array}$ \\
\hline 1 & temperate cereals & Wheat grain & 18.2 \\
2 & rice & Rice & 15.3 \\
3 & maize & Maize & 17.7 \\
4 & tropical cereals & Millet & 18.9 \\
5 & pulses & Pulses & 17.2 \\
6 & temperate roots & Potato/Beet & 17.7 \\
7 & tropical roots & Cassava & 17.3 \\
8 & oil crops sunflower & Sunflower oil (seeds) & 27.8 \\
9 & oil crops soybean & Soybean oil (seeds) & 23.4 \\
10 & oil crops groundnut & Groundnut oil (seeds) & 29.4 \\
11 & oil crops rapeseed & Rapeseed oil (seeds) & 28.1 \\
12 & sugarcane & Sugarcane & 17.0 \\
13 & managed grass & Others (managed grass) & 18.6 \\
15 & biomass grass & Avg. of Miscanthus \& Switchgrass & 18.5 \\
16 & biomass tree & Avg. of Poplar \& Eucalyptus & 20.0 \\
\hline
\end{tabular}

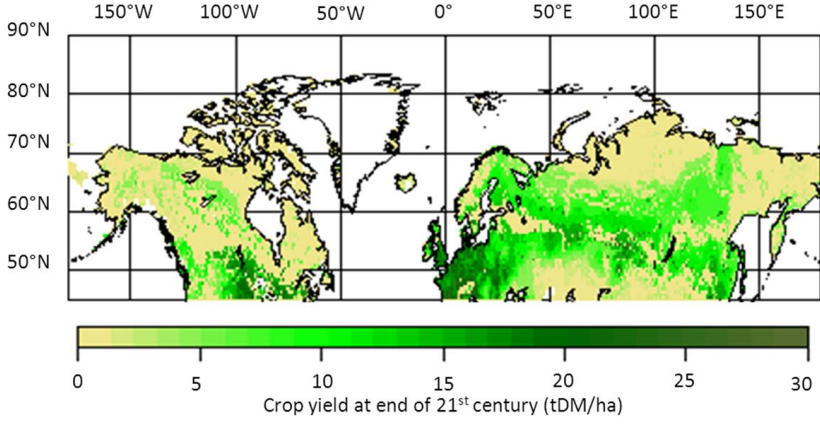

Fig. 6. The crop yield (tDM/ha) at the end of the 21 st century for the UNLIM scenario. The values plotted are a mean of the 19 values simulated by LPJmL as a result of using climate data simulated by 19 GCMs (Table 1).

based estimate of global mean warming to cumulative emissions at $\mathrm{CO}_{2}$ doubling ranges from 0.8 to $2.1 \mathrm{~K}$ per $1000 \mathrm{GtC}$ emissions. While this metric is simplified and linear, it could be used as a first-order simplified method in our study since it accounts for response of the ocean carbon system on multidecadal timescale. Applying this metric to the range 102.2 to $569.5 \mathrm{GtC}$ of cumulative saved emissions at the end of the 21 st century, we can estimate an avoided warming of 0.08 to $1.2{ }^{\circ} \mathrm{C}$ (Table 5) due to extensive bioenergy crop plantations on the deforested area north of $45^{\circ} \mathrm{N}$. This is in addition to the predominantly albedo-driven cooling from the largescale deforestation of the high latitudes.

To analyze the changes in temperature from purely biogeophysical effects of such large-scale deforestation, we analyze the results from the additional experiment with MPIESM. To exclude the small trend during the first few years, we report changes averaged over the last $20 \mathrm{yr}$ of the $30 \mathrm{yr}$ experiment. We find a decrease in the global mean annual

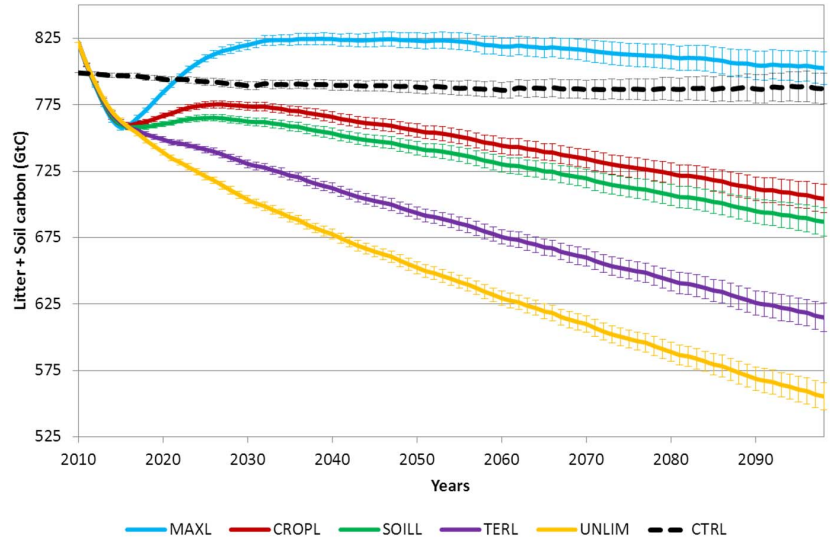

Fig. 7. Long-term carbon emissions from the litter and soil carbon pools of the respective land management scenarios (solid colored lines) compared with that of CTRL (dashed black line). The mean of an ensemble of 19 values is shown by the thick line while the error bars represent the uncertainty (1 standard deviation). After an initial decrease, the carbon pools of soil and litter start recovering as natural grassland is allowed to regrow on areas not used for bioenergy cropping. The difference in carbon pools of the different land management scenarios is because of the different extents of land under bioenergy cultivation. MAXL, the most plausible scenario, has the least land under cultivation and thus has the most land under natural grassland. As grassland soils have more carbon than that of woody forests, the sum of litter and soil carbon of MAXL exceeds that of CTRL.

near-surface air temperature by $0.35 \pm 0.17^{\circ} \mathrm{C}$ and the regional cooling by more than $4^{\circ} \mathrm{C}$ compared to the control simulation (Fig. 10). This temperature change is mainly a result of an increase in albedo, reflected by the increase in the surface upwelling shortwave radiation (Fig. 11). The biogeophysical effects of boreal deforestation could also be 
Table 3. Lower and upper temperature limits for optimal photosynthesis for all CFTs.

\begin{tabular}{llcc}
\hline CFT & CFT name & $\begin{array}{c}\text { Lower } \\
\text { temp - } \\
\text { optimal } \\
\text { photosynthesis } \\
\left({ }^{\circ} \mathrm{C}\right)\end{array}$ & $\begin{array}{c}\text { Upper } \\
\text { temp - } \\
\text { optimal } \\
\text { photosynthesis } \\
\left({ }^{\circ} \mathrm{C}\right)\end{array}$ \\
\hline 1 & temperate cereals & 12 & 17 \\
2 & rice & 20 & 45 \\
3 & maize & 21 & 26 \\
4 & tropical cereals & 20 & 45 \\
5 & pulses & 10 & 30 \\
6 & temperate roots & 10 & 30 \\
7 & tropical roots & 20 & 45 \\
8 & oil crops sunflower & 25 & 32 \\
9 & oil crops soybean & 28 & 32 \\
10 & oil crops groundnut & 20 & 45 \\
11 & oil crops rapeseed & 12 & 17 \\
12 & sugarcane & 18 & 30 \\
13 & managed grass C3/C4 & $10 / 20$ & $30 / 45$ \\
14 & biomass grass & 15 & 45 \\
15 & biomass tree & 15 & 30 \\
\hline
\end{tabular}

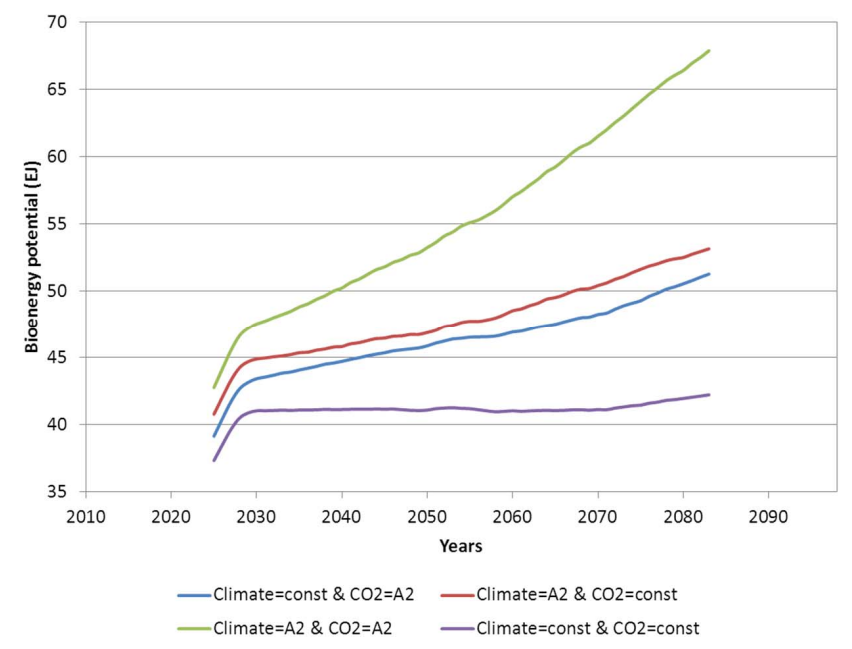

Fig. 8. Sensitivity of biophysical bioenergy potentials of the most plausible scenario, i.e. MAXL, to changes in climate (simulated by ECHAM5 model only) and/or $\mathrm{CO}_{2}$ shown as a $30 \mathrm{yr}$ moving average. The purple line at the bottom stands for the scenario where there is no change in climate or $\mathrm{CO}_{2}$, while the green line at the top represents the scenario where both climate as well as $\mathrm{CO}_{2}$ change according to the SRES A2 scenario. The land use for all the scenarios remain constant. Since perennial bioenergy grasses need a few years to reach full productivity in LPJmL, the total bioenergy potential is lower in the first years.

understood by analyzing the change of surface energy balance, as tabulated in Table 6.

We assume in this study that bioenergy production is carbon neutral (except for the land use change emissions). Thus in spite of the large emissions due to the large-scale deforestation, bioenergy production could potentially lead to

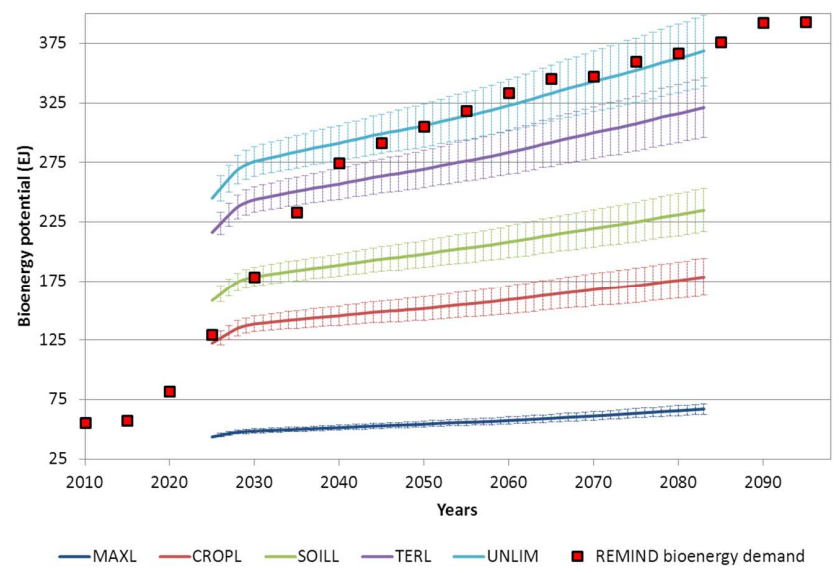

Fig. 9. Total biophysical bioenergy potentials of the area north of $45^{\circ} \mathrm{N}$ for the respective land management scenarios. To put the potentials into perspective, we have plotted the bioenergy demand (red dots) as simulated by REMIND-R for the "Biomass-max" scenario (Leimbach et al., 2010b). The values plotted are a $30 \mathrm{yr}$ moving average. The thick line represents the mean of 19 values while the uncertainty ( 1 standard deviation) is shown by the error bars. Since perennial bioenergy grasses need a few years to reach full productivity in LPJmL, the total bioenergy potential is lower in the first years.

savings of carbon emissions in the long term if the "carbon debt" caused by the deforestation is "repaid" (Fargione et al., 2008) by the carbon saved by the avoided use of fossil fuels. However as evident from Fig. 12, this cannot be achieved within the 21 st century in the most realistic land use scenario MAXL. It takes more than $60 \mathrm{yr}$ in the unlimited or most idealistic scenario UNLIM to repay this carbon debt. Using the metric of transient climate sensitivity to cumulative emissions (Gillett et al., 2013; Matthews et al., 2009) and subtracting the cumulative carbon saved from the total emissions at the end of the 21 st century, but ignoring biogeophysical feedback, we estimate that the global anthropogenic warming is increased by 0.04 to $0.11^{\circ} \mathrm{C}$ for the MAXL scenario as the carbon debt is not neutralized within the 21 st century. However, for the less constrained and more hypothetical scenarios, the global anthropogenic warming of 0.02 to $0.35^{\circ} \mathrm{C}$ could be theoretically avoided under the scenarios CROPL, SOILL, TERL and UNLIM (Table 5).

\section{Discussion}

The conclusion that a biogeophysical cooling would dominate over a biogeochemical warming as a result of deforestation of the high latitudes, as suggested by previous studies (Bala et al., 2007; Bathiany et al., 2010) is being re-assessed here. There is a significantly large disparity between previous and this study in the deforestation-induced carbon emissions. Bathiany et al. (2010) had concluded that boreal deforestation or removal of all vegetation other than grass would 
Table 4. Different land management scenarios (their restrictions included), the corresponding area available for bioenergy plantations, the corresponding emissions and resultant increase in temperature because of that at the end of the 21 st century.

\begin{tabular}{|c|c|c|c|c|c|}
\hline Scenario & Restrictions & $\begin{array}{r}\text { Area } \\
\text { (Million } \\
\text { Hectares) }\end{array}$ & $\begin{array}{r}\text { Long-term } \\
\text { emissions } \\
(\mathrm{GtC})\end{array}$ & $\begin{array}{r}\text { Total } \\
\text { emissions at } \\
\text { end of } 21 \mathrm{st} \\
\text { century } \\
(\mathrm{GtC})\end{array}$ & $\begin{array}{c}\text { Increase of } \\
\text { global mean } \\
\text { temperature at } \\
\text { end of } 21 \mathrm{st} \\
\text { century only } \\
\text { due to } \\
\text { emissions }\left({ }^{\circ} \mathrm{C}\right)\end{array}$ \\
\hline MAXL & $\begin{array}{l}\text { Terrain }+ \text { soil }(\text { depth, drainage, texture, } \\
\text { chemical })+ \text { built area }+ \text { cropped land }+ \\
\text { soil fertility }\end{array}$ & 536.7 & $-13.7 \pm 8.2$ & $168.5 \pm 8.6$ & 0.12 to 0.32 \\
\hline CROPL & $\begin{array}{l}\text { Terrain }+ \text { soil (depth, drainage, texture, } \\
\text { chemical })+ \text { built area }+ \text { cropped land }\end{array}$ & 1787.7 & $83.7 \pm 12.0$ & $266.0 \pm 12.5$ & 0.20 to 0.53 \\
\hline SOILL & $\begin{array}{l}\text { Terrain }+ \text { soil (depth, drainage, texture, } \\
\text { chemical) }\end{array}$ & 2073.2 & $101.1 \pm 12.3$ & $283.4 \pm 12.8$ & 0.22 to 0.57 \\
\hline TERL & Terrain & 3121.4 & $172.6 \pm 14.0$ & $354.9 \pm 14.5$ & 0.27 to 0.72 \\
\hline UNLIM & None & 3801.4 & $231.7 \pm 15.0$ & $414.0 \pm 15.5$ & 0.32 to 0.84 \\
\hline
\end{tabular}

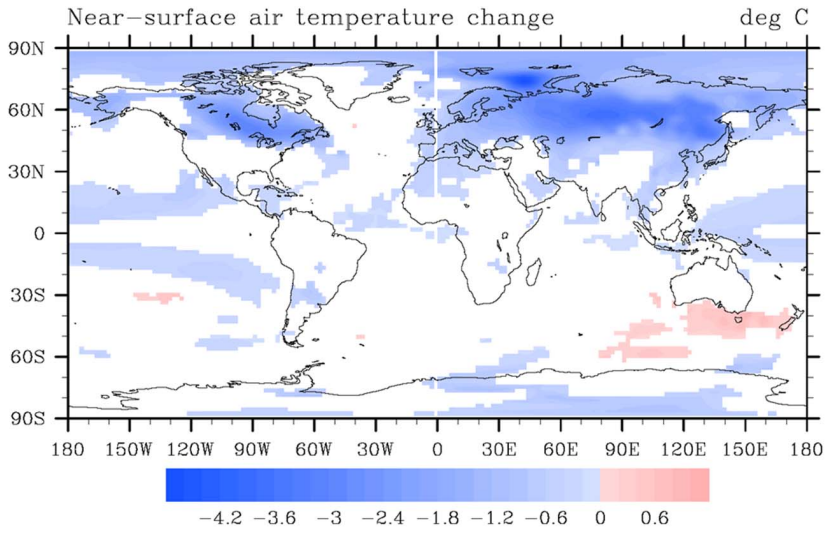

Fig. 10. The change of annual near-surface air temperature $\left({ }^{\circ} \mathrm{C}\right)$ in response to high-latitude deforestation. Shown is the difference between the MPI-ESM boreal deforestation experiment, averaged over the last $20 \mathrm{yr}$ and the pre-industrial control simulation. Shown are only statistically significant changes $(p<0.05)$.

result in a net global cooling of $0.25^{\circ} \mathrm{C}$ as biogeophysical effects dominate over the immediate emission of $20 \mathrm{GtC}$. They found the changes in global terrestrial carbon being close to zero as the enhanced productivity of the tropics compensate for the slow soil respiration of the cold regions. On the other hand, Bala et al. (2007) found a reduction of global mean temperature by $0.8^{\circ} \mathrm{C}$ at the end of the 21 st century as cooling biogeophysical effects overwhelmed an emission of 80 $\mathrm{GtC}$ due to tree removal. Our study using LPJmL suggests that the clearing and consequently burning of all natural vegetation, woody and herbaceous, from the land north of $45^{\circ} \mathrm{N}$ results in the immediate emission of $\sim 182 \mathrm{GtC}$ which is

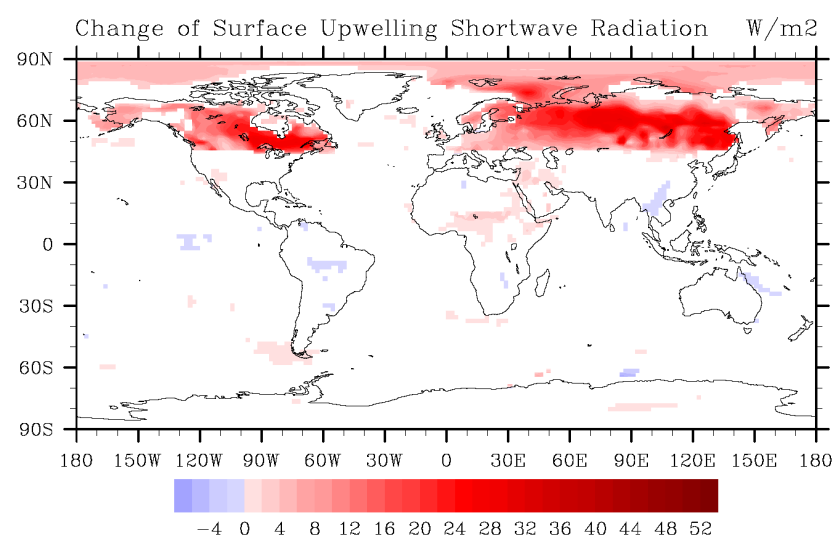

Fig. 11. The same as Fig. 10 but for the change of annual surface upwelling shortwave radiation $\left(\mathrm{W}^{2}\right)$.

much higher. Moreover, it is followed by long-term changes in the litter and soil carbon pools ranging from a sequestration of $\sim 14 \mathrm{GtC}$ for the most realistic scenario (MAXL) to an emission of $\sim 232 \mathrm{GtC}$ for the most idealistic scenario (UNLIM) by the end of the 21st century.

The mismatch in the carbon emissions reflects the difference in how "deforestation" is simulated in these studies. In Bala et al. (2007) deforestation meant removal of trees, in Bathiany et al. (2010) it meant the removal of all vegetation other than grass and as immediate emissions, only $50 \%$ of the aboveground vegetation carbon was released to the atmosphere. In this study using LPJmL, deforestation meant complete removal of any kind of natural vegetation, leaving behind bare ground. This mismatch in the carbon emissions also reflects the different representation of the carbon 
Table 5. The bioenergy potentials, the cumulative carbon saved by avoided burning of fossil fuels and the corresponding potential additional cooling of the respective land management scenarios.

\begin{tabular}{lllcc}
\hline Scenario & $\begin{array}{l}\text { Bioenergy } \\
\text { potential at end of } \\
21 \text { st century }(30 \mathrm{yr} \\
\text { mean) }\left(\mathrm{EJ} \mathrm{yr}^{-1}\right)\end{array}$ & $\begin{array}{l}\text { Cumulative } \\
\text { carbon saved at } \\
\text { end of } 21 \mathrm{st} \\
\text { century (avoided } \\
\text { fossil fuel } \\
\text { burning) }(\mathrm{GtC})\end{array}$ & $\begin{array}{c}\text { Additional cooling } \\
\text { cause by } \\
\text { bioenergy } \\
\text { cropping at end of } \\
\text { 21st century }\left({ }^{\circ} \mathrm{C}\right)\end{array}$ & $\begin{array}{c}\text { Net change of } \\
\text { global mean } \\
\text { temperature (net } \\
\text { biogeochemical } \\
\text { effects only) }\left({ }^{\circ} \mathrm{C}\right)\end{array}$ \\
\hline MAXL & $68.1 \pm 5.6$ & $102.2 \pm 5.1$ & 0.08 to 0.21 & +0.04 to +0.11 \\
CROPL & $177.3 \pm 16.5$ & $280.0 \pm 19.7$ & 0.22 to 0.59 & -0.02 to -0.06 \\
SOILL & $233.4 \pm 20.0$ & $366.0 \pm 22.6$ & 0.29 to 0.77 & -0.08 to -0.20 \\
TERL & $320.9 \pm 28.1$ & $499.4 \pm 31.3$ & 0.40 to 1.05 & -0.13 to -0.33 \\
UNLIM & $373.8 \pm 33.4$ & $569.5 \pm 36.6$ & 0.46 to 1.20 & -0.14 to -0.35 \\
\hline
\end{tabular}

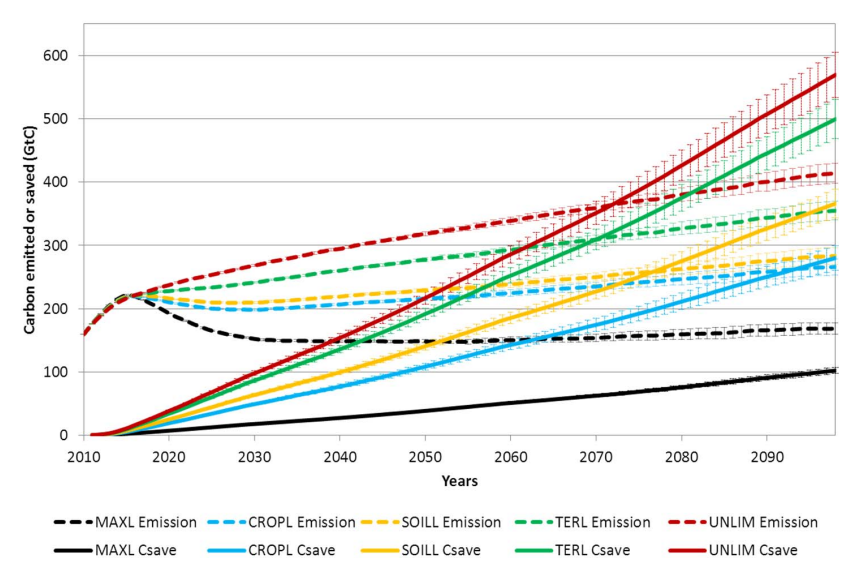

Fig. 12. Time to repay carbon debt for the respective scenarios. We show the total emissions incurred due to bioenergy cultivation (dashed line) and the carbon emissions saved potentially for each of the scenarios through avoided use of fossil fuels (solid line) with each color unique to the respective land management scenarios. The time taken for the lines of the respective scenarios (colors) to intersect gives us the time to repay the carbon debt. While the thick or dashed line represents the mean of 19 values, the uncertainty (1 standard deviation) is shown by the error bars.

cycle in LPJmL (Bondeau et al., 2007; Sitch et al., 2003), JSBACH (Raddatz et al., 2007) (land surface model of MPIESM) and INNCCA (Bala et al., 2005; Thompson et al., 2004). In general, compared to observations (Prentice et al., 2001) JSBACH underestimates carbon pools of plant and litter in the boreal latitudes (Bathiany et al., 2010). In the preindustrial experiment with MPI-ESM, we find that the equilibrium boreal carbon storage (for pre-industrial $\left[\mathrm{CO}_{2}\right]$ ) is $29 \mathrm{MgC} \mathrm{ha}^{-1}$ averaged over all land north of $45^{\circ} \mathrm{N}$, which is an underestimation compared to the range of observed values of 42 to $64 \mathrm{MgC} \mathrm{ha}^{-1}$ (Prentice et al., 2001). On the contrary, the average vegetation carbon for the same region computed by LPJmL is $53.2 \mathrm{MgC} \mathrm{ha}^{-1}$ which is within the range of observed values as mentioned above. However, compared to observational data, LPJmL overestimates the immediate
Table 6. The annual surface energy balance averaged over land cells north of $45^{\circ} \mathrm{N}$ over the last $20 \mathrm{yr}$ of the MPI-ESM boreal deforestation experiment. Values for the experiments are given as deviations of boreal deforestation experiment $(\Delta \mathrm{Def})$ from the control climate (CTRL). All fluxes are in $\mathrm{Wm}^{-2}$, surface temperature in ${ }^{\circ} \mathrm{C}$. $\mathrm{SW}=$ shortwave radiation; $\mathrm{LW}=$ longwave radiation; $\mathrm{LH}=$ surface upwards latent heat flux; $\mathrm{SH}=$ surface upwards sensible heat flux; Temp $=$ near-surface air temperature.

\begin{tabular}{lrr}
\hline Values & CTRL & $\Delta$ Def \\
\hline $\begin{array}{l}\text { Surface upwelling SW } \\
\text { (proxy for albedo) }\end{array}$ & 30.7 & +12.4 \\
Net SW (downwards - upwards) & 86.9 & -8.0 \\
Net LW (downwards - upwards) & -43.6 & +1.5 \\
Net radiation (SW + LW) & 43.3 & -6.5 \\
LH & 30.3 & -3.7 \\
SH & 11.7 & -2.8 \\
Temp & -2.8 & -1.9 \\
\hline
\end{tabular}

emissions. According to 2007 estimates, the carbon stock in the living biomass in the boreal forest and half of the temperate forests of the Northern Hemisphere amounts to $\sim 73 \mathrm{GtC}$ (Pan et al., 2011) and this study computes the immediate emissions, or the carbon emitted when the living biomass is burnt completely to be $\sim 182 \mathrm{GtC}$. Compared to satellite data, LPJ (predecessor of LPJmL and represents only natural vegetation) also overpredicts the coverage of deciduous broad-leaved vegetation in the boreal forests of Canada and Eurasia (Sitch et al., 2003). Hickler et al. (2006) found that while comparing vegetation modeled by LPJ with potentially occurring vegetation, the agreement is reasonably good for all vegetation types of the high latitudes except for temperate conifer forests. Brovkin et al. (2012) show that LPJmL overestimates litter stocks in the polar tundra region while the woody litter is underestimated in all other regions. These disagreements thus have its consequent effects on the carbon cycle. Apart from this, it is well documented that LPJmL 
is able to reproduce key features of the global carbon cycle (Jung et al., 2008; Luyssaert et al., 2010).

With respect to the biogeophysical feedback, the albedo of herbaceous bioenergy crops is essentially similar to grass, especially when covered by snow in the winter months (Robinson and Kukla, 1984). Moreover it has often been observed that even shrubs and consequently herbaceous crops are bent over and buried by a depth of snow that is less than their height when erect (Bewley et al., 2010). Thus when covered by snow all herbaceous crops would have a similar albedo as even tall grasses would be bent over by snow. This means that if the forests of high latitudes were hypothetically removed and planted with bioenergy crops, we could expect a similar biogeophysical effect as we find in our additional experiment with MPI-ESM (a reduction in global mean annual temperature by $0.35 \pm 0.17^{\circ} \mathrm{C}$ for complete boreal deforestation). We also find that this biogeophysical effect is similar to other large-scale deforestation experiments (e.g. Bala et al., 2007; Bathiany et al., 2010).

Even though biophysical bioenergy potentials can be substantial, for instance in projected high bioenergy demand scenarios (Leimbach et al., 2010a,b), these are strongly dependent on the assumption of how much of the deforested area could effectively and efficiently be managed. Bright et al. (2011) who study the effects of bioenergy production from production forests of Norway on the radiative forcing also found that in the long term the negative radiative forcing from avoided fossil fuel emission (biogeochemical effect) plays a more active role compared to the negative forcing due to albedo changes (biogeophysical effect).

Various studies show that the soil carbon does reduce after forest clearing followed by agriculture, but the magnitude of $\mathrm{CO}_{2}$ emissions from soils could be overestimated if the change in bulk density of the soil is not considered (Karhu et al., 2011; Murty et al., 2002). Our study also shows a decrease of soil carbon after conversion of land cover from forest to agriculture. However as LPJmL does not estimate the change in soil bulk density, it would overestimate the emissions from soils.

In order to compare similar units of energy we have computed and compared only primary energy, i.e. assuming $100 \%$ combustion efficiency. However, during the commercial exploitation of this bioenergy, there is a loss of energy when plant material is converted from its natural form to a form which can be commercially used. This feedstock conversion efficiency ranges from as low as $17 \%$ for sugarcane to around $50 \%$ for corn and wheat to as high as approximately $100 \%$ for soy and palm oil (Bruckner et al., 2011). Similarly, fossil fuels have varying moisture and ash content and thus have different energy densities (Reed, 2010). On top of this there is loss of energy depending on different energy conversion efficiencies of the final device being powered by the respective fuels.

The long-term fertilization effects due to increasing temperature and $\mathrm{CO}_{2}$ simulated by LPJmL and as shown in
Fig. 8 are optimistic, as nitrogen dynamics and its limiting effect on $\mathrm{CO}_{2}$ fertilization (Oren et al., 2001; Reich et al., 2006) are omitted here. Thus the increasing trend of productivity shown in this study assumes that current management intensity levels can be maintained also with respect to soil fertility. Moreover, while most of the area investigated in this study is permafrost, the carbon dynamics of permafrost are not represented here. So we ignore the additional $\mathrm{CO}_{2}$ and $\mathrm{CH}_{4}$ emissions from permafrost soils due to climate change (Koven et al., 2011; Schaefer et al., 2011; Schneider von Deimling et al., 2012; Zimov et al., 2006) and disturbance (Myers-Smith et al., 2007).

The climate and $\mathrm{CO}_{2}$ data used by LPJmL is according to the SRES A2 scenario, which does not include any form of climate mitigation (Nakicenovic et al., 2000). We thus get an increasing trend of biophysical bioenergy potentials as $\mathrm{CO}_{2}$ and temperature continuously increase over the 21 st century. The mitigating effect of large-scale bioenergy production on climate is not considered here. To include these feedbacks, a full coupling of the carbon cycle and the climate system would be necessary.

The different land management scenarios assumed here involve different management measures. All forms of management, especially the application of fertilizers and agricultural machinery, would result in additional emissions. For example, a 2002 report suggested that the production of ammonia consumed about $5 \%$ of global natural gas production, which is somewhat under $2 \%$ of the world energy production (International Fertilizer Industry Association, 2002). Irrespective of management, there would be additional emissions for other agriculture-based activities like crop harvest and transportation, which have not been considered here.

Carrying out such a large-scale deforestation would be impractical and in reality one would only deforest those areas which would be suitable for bioenergy cropping. However we do not perform such an experiment with LPJmL as otherwise this study would not be comparable with that of Bala et al. (2007) and Bathiany et al. (2010). In a study by Brovkin et al. (2013) we see that the changes in climate simulated by ESMs are relatively small in comparison with interannual variability of climate and are difficult to detect when the land use changes are small. For this reason, small-scale deforestation experiments are not carried out in the boreal deforestation experiments using MPI-ESM.

\section{Conclusions}

Comparing this study's results to those of Bathiany et al. (2010) and Bala et al. (2007), we find much higher carbon emissions from high-latitude deforestation both for immediate as well as long-term emissions. If bioenergy is to be produced in the suitable parts of the deforested area, considering limitations in terrain, soil conditions and land that is currently built or cropped, bioenergy production saves 
carbon emissions through avoided combustion of fossil fuels, thereby reducing the carbon debt. The global mean temperature change at the end of the 21 st century, due to deforestation emissions for the most realistic scenario, ranges from +0.12 to $+0.32{ }^{\circ} \mathrm{C}$, depending on the climate sensitivity. Since the most realistic scenario involves only about $14 \%$ of the total deforested area for bioenergy cropping, the carbon debt caused by the deforestation emissions is not compensated for by the bioenergy plantations by the end of the 21st century, leading to a net increase in anthropogenic warming. Considering the net effect of deforestation emissions and bioenergy substituting fossil fuel emissions, the global mean temperature at the end of the 21 st century is found to increase by 0.04 to $0.11^{\circ} \mathrm{C}$ compared to the preexperimental period.

Taking into account the pure biogeophysical effects of high-latitude deforestation, we find the near-surface global mean temperature to decrease by $0.35 \pm 0.17^{\circ} \mathrm{C}$. The biogeochemical and biogeophysical effects have been computed separately by different models, having different spatial resolutions and having harmonized but different experimental setups. Therefore the effects on global mean temperature have been reported separately and have not been compared quantitatively or added to produce a net result.

A number of issues like realistic combustion efficiencies of fuels, nitrogen dynamics, carbon dynamics of the permafrost, mitigation effects of large-scale bioenergy plantation and emissions from different management measures have not been accounted for in this study. These, as well as a better assessment of biogeochemical versus biogeophysical effects, need further consideration in future studies to make a better assessment of the impact of boreal deforestation for bioenergy production. In addition, given the strong impact on the land's biosphere carbon cycle and non-assessment of other detrimental effects such as destruction of landscapes and reduction of biodiversity, all studies, including this, have not promoted large-scale deforestation as a measure to mitigate anthropogenic climate change. Large-scale deforestation experiments must therefore remain purely theoretical experiments.

Acknowledgements. The authors thank Fanny Langerwisch for helping in setting up the model, Tim Beringer, Sibyll Schaphoff, and Werner von Bloh for extending the model LPJmL and maintaining the model code.

Edited by: L. Ganzeveld

\section{References}

Adler, P. R., Grosso, S. J. D., and Parton, W. J.: Life-cycle assessment of net greenhouse-gas flux for bioenergy cropping systems, Ecol. Appl., 17, 675-691, 2007.

Alton, P.: A simple retrieval of ground albedo and vegetation absorptance from MODIS satellite data for parameterisation of global Land-Surface Models, Agr. Forest Meteorol., 149, 17691775, 2009.

Arora, V. K. and Montenegro, A.: Small temperature benefits provided by realistic afforestation efforts, Nature Geosci, 4, 514518, doi:10.1038/ngeo1182, 2011.

Bala, G., Caldeira, K., Mirin, A., Wickett, M., and Delire, C.: Multicentury Changes to the Global Climate and Carbon Cycle: Results from a Coupled Climate and Carbon Cycle Model, J. Climate, 18, 4531-4544, doi:10.1175/JCLI3542.1, 2005.

Bala, G., Caldeira, K., Wickett, M., Phillips, T. J., Lobell, D. B., Delire, C., and Mirin, A.: Combined climate and carbon-cycle effects of large-scale deforestation, P. Natl. Acad. Sci., 104, 6550 6555, doi:10.1073/pnas.0608998104, 2007.

Bathiany, S., Claussen, M., Brovkin, V., Raddatz, T., and Gayler, V.: Combined biogeophysical and biogeochemical effects of largescale forest cover changes in the MPI earth system model, Biogeosciences, 7, 1383-1399, doi:10.5194/bg-7-1383-2010, 2010.

Beringer, T., Lucht, W., and Schaphoff, S.: Bioenergy production potential of global biomass plantations under environmental and agricultural constraints, GCB Bioenergy, 3, 299-312, 2011.

Betts, R. A.: Offset of the potential carbon sink from boreal forestation by decreases in surface albedo, Nature, 408, 187-190, 2000.

Bewley, D., Essery, R., Pomeroy, J., and Ménard, C.: Measurements and modelling of snowmelt and turbulent heat fluxes over shrub tundra, Hydrol. Earth Syst. Sci., 14, 1331-1340, doi:10.5194/hess-14-1331-2010, 2010.

Bonan, G. B.: Forests and Climate Change: Forcings, Feedbacks, and the Climate Benefits of Forests, Science, 320, 1444-1449, doi:10.1126/science.1155121, 2008.

Bondeau, A., Smith, P. C., Zaehle, S., Schaphoff, S., Lucht, W., Cramer, W., Gerten, D., Lotze-Campen, H., Müller, C., Reichstein, M., and Smith, B.: Modelling the role of agriculture for the 20th century global terrestrial carbon balance, Global Change Biol., 13, 679-706, doi:10.1111/j.13652486.2006.01305.x, 2007.

Bounoua, L., DeFries, R., Collatz, G. J., Sellers, P., and Khan, H.: Effects of land cover conversion on surface climate, Climatic Change, 52, 29-64, 2002.

Bright, R. M., Strømman, A. H., and Peters, G. P.: Radiative Forcing Impacts of Boreal Forest Biofuels: A Scenario Study for Norway in Light of Albedo, Environ. Sci. Technol., 45, 7570-7580, doi:10.1021/es201746b, 2011.

Brovkin, V., Claussen, M., Driesschaert, E., Fichefet, T., Kicklighter, D., Loutre, M. F., Matthews, H. D., Ramankutty, N., Schaeffer, M., and Sokolov, A.: Biogeophysical effects of historical land cover changes simulated by six Earth system models of intermediate complexity, Clim. Dynam., 26, 587-600, doi:10.1007/s00382-005-0092-6, 2006.

Brovkin, V., Raddatz, T., Reick, C. H., Claussen, M., and Gayler, V.: Global biogeophysical interactions between forest and climate, Geophys. Res. Lett., 36, L07405, doi:10.1029/2009GL037543, 2009. 
Brovkin, V., van Bodegom, P. M., Kleinen, T., Wirth, C., Cornwell, W. K., Cornelissen, J. H. C., and Kattge, J.: Plant-driven variation in decomposition rates improves projections of global litter stock distribution, Biogeosciences, 9, 565-576, doi:10.5194/bg-9-5652012, 2012.

Brovkin, V., Boysen, L., Arora, V. K., Boisier, J. P., Cadule, P., Chini, L., Claussen, M., Friedlingstein, P., Gayler, V., van den Hurk, B. J. J. M., Hurtt, G. C., Jones, C. D., Kato, E., de NobletDucoudré, N., Pacifico, F., Pongratz, J. and Weiss, M.: Effect of Anthropogenic Land-Use and Land-Cover Changes on Climate and Land Carbon Storage in CMIP5 Projections for the TwentyFirst Century, J. Climate, 26, 6859-6881, doi:10.1175/JCLI-D12-00623.1, 2013.

Bruckner, T., Chum, H., Jäger-Waldau, A., Killingtveit, A., Gutiérrez-Negrín, L., Nyboer, J., Musial, W., Verbruggen, A., and Wiser, R.: Annex III: Cost Table, in: IPCC Special Report on Renewable Energy Sources and Climate Change Mitigation, edited by: Edenhofer, O., Pichs-Madruga, R., Sokona, Y., Seyboth, K., Seyboth, K., Matschoss, P., Kadner, S., Zwickel, T., Eickemeier, P., Hansen, G., Schlömer, S., and von Stechow, C., Cambridge University Press, Cambridge, UK and New York, NY, USA, 2011.

Cherubini, F., Bright, R. M., and Strømman, A. H.: Site-specific global warming potentials of biogenic $\mathrm{CO}_{2}$ for bioenergy: contributions from carbon fluxes and albedo dynamics, Environ. Res. Lett., 7, 045902, doi:10.1088/1748-9326/7/4/045902, 2012a.

Cherubini, F., Guest, G., and Strømman, A. H.: Application of probability distributions to the modeling of biogenic $\mathrm{CO} 2$ fluxes in life cycle assessment, GCB Bioenergy, 4, 784-798, doi:10.1111/j.1757-1707.2011.01156.x, 2012b.

Claussen, M., Brovkin, V., and Ganopolski, A.: Biogeophysical versus biogeochemical feedbacks of large-scale land cover change, Geophys. Res. Lett., 28, 1011-1014, 2001

Conant, R. T., Paustian, K. and Elliott, E. T.: Grassland management and conversion into grassland: effects on soil carbon, Ecol. Appl., 11, 343-355, doi:10.1890/10510761(2001)011[0343:GMACIG]2.0.CO;2, 2001.

Crutzen, P. J., Mosier, A. R., Smith, K. A., and Winiwarter, W.: $\mathrm{N}_{2} \mathrm{O}$ release from agro-biofuel production negates global warming reduction by replacing fossil fuels, Atmos. Chem. Phys., 8, 389-395, doi:10.5194/acp-8-389-2008, 2008.

Davidson, E. A. and Ackerman, I. L.: Changes in soil carbon inventories following cultivation of previously untilled soils, Biogeochemistry, 20, 161-193, doi:10.1007/BF00000786, 1993.

ECN: Phyllis, the composition of biomass and waste, available from: http://www.ecn.nl/phyllis/ (last access: 4 June 2012), 2007.

EIA: Voluntary Reporting of Greenhouse Gases Program Fuel Emission Coefficients, available from: http://www.eia.gov/oiaf/ 1605/coefficients.html (last access: 24 July 2012), 2008.

Ellert, B. and Gregorich, E.: Storage of carbon, nitrogen and phosphorus in cultivated and adjacent forested soils of Ontario, Soil Sci., 161, 587-603, 1996

Erb, K.-H., Gaube, V., Krausmann, F., Plutzar, C., Bondeau, A., and Haberl, H.: A comprehensive global 5 min resolution land-use data set for the year 2000 consistent with national census data, J. Land Use Sci., 2, 191-224, doi:10.1080/17474230701622981, 2007.
Fader, M., Rost, S., Müller, C., Bondeau, A., and Gerten, D.: Virtual water content of temperate cereals and maize: Present and potential future patterns, J. Hydrol., 384, 218-231, 2010.

FAOSTAT: Agriculture Organization of the United Nations, Statistical Database, available from: http://faostat.fao.org/, last access: 27 February 2009.

Fargione, J., Hill, J., Tilman, D., Polasky, S., and Hawthorne, P.: Land Clearing and the Biofuel Carbon Debt, Science, 319, 1235 1238, doi:10.1126/science.1152747, 2008.

Fischer, G. and Schrattenholzer, L.: Global bioenergy potentials through 2050, Biomass Bioenergy, 20, 151-159, doi:10.1016/S0961-9534(00)00074-X, 2001.

Fischer, G., Velthuizen, H. V., Nachtergaele, F. O., and Jernelöv, A.: Global Agro-Ecological Zones Assessment: Methodology and Results, available from: http://www.iiasa.ac.at/Research/LUC/ GAEZ/index.htm (last access: 18 June 2012), 2000.

Gerten, D., Heinke, J., Hoff, H., Biemans, H., Fader, M., and Waha, K.: Global Water Availability and Requirements for Future Food Production, J. Hydrometeorol., 12, 885-899, doi:10.1175/2011JHM1328.1, 2011

Gillett, N. P., Arora, V. K., Matthews, D., and Allen, M. R.: Constraining the ratio of global warming to cumulative $\mathrm{CO}_{2}$ emissions using CMIP5 simulations, J. Climate, doi:10.1175/JCLID-12-00476.1, in press, 2013.

Giorgetta, M. A., Jungclaus, J., Reick, C. H., Legutke, S., Bader, J., Böttinger, M., Brovkin, V., Crueger, T., Esch, M., Fieg, K., Glushak, K., Gayler, V., Haak, H., Hollweg, H.-D., Ilyina, T., Kinne, S., Kornblueh, L., Matei, D., Mauritsen, T., Mikolajewicz, U., Mueller, W., Notz, D., Pithan, F., Raddatz, T., Rast, S., Redler, R., Roeckner, E., Schmidt, H., Schnur, R., Segschneider, J., Six, K. D., Stockhause, M., Timmreck, C., Wegner, J., Widmann, H., Wieners, K.-H., Claussen, M., Marotzke, J. and Stevens, B.: Climate and carbon cycle changes from 1850 to 2100 in MPI-ESM simulations for the Coupled Model Intercomparison Project phase 5, J. Adv. Model. Earth Syst., 5, 572-597, doi:10.1002/jame.20038, 2013.

Grünzweig, J. M., Sparrow, S. D., Yakir, D., and Stuart Chapin, F.: Impact of Agricultural Land-use Change on Carbon Storage in Boreal Alaska, Global Change Biol., 10, 452-472, doi:10.1111/j.1365-2486.2004.00738.x, 2004.

Guo, L. B. and Gifford, R. M.: Soil carbon stocks and land use change: a meta analysis, Global Change Biol., 8, 345-360, doi:10.1046/j.1354-1013.2002.00486.x, 2002.

Hickler, T., Prentice, I. C., Smith, B., Sykes, M. T., and Zaehle, S.: Implementing plant hydraulic architecture within the LPJ Dynamic Global Vegetation Model, Global Ecol. Biogeogr., 15, 567-577, doi:10.1111/j.1466-8238.2006.00254.x, 2006

Holland, M. M. and Bitz, C. M.: Polar amplification of climate change in coupled models, Clim. Dynam., 21, 221-232, doi:10.1007/s00382-003-0332-6, 2003.

Houghton, R., Hobbie, J., Melillo, J. M., Moore, B., Peterson, B., Shaver, G., and Woodwell, G.: Changes in the Carbon Content of Terrestrial Biota and Soils between 1860 and 1980: A Net Release of $\mathrm{CO}_{2}$ to the Atmosphere, Ecological Monogr., 53, 235$262,1983$.

International Fertilizer Industry Association: Fertilizer Indicators, available from: http://www.fertilizer.org/ifa/statistics/indicators/ ind_cnworld.asp (last access: 27 July 2012), 2002. 
IPCC: Climate change 2007: the Physical Science Basis. Contribution of Working Group I to the Fourth Assessment Report of the Intergovernmental Panel on Climate Change, edited by: Solomon, S., Qin, D., Manning, M., Chen, Z., Marquis, M., Averyt, K., Tignor, M., and Miller, H., Cambridge University Press, Cambridge, UK and New York, NY, USA, 2007.

Jung, M., Verstraete, M., Gobron, N., Reichstein, M., Papale, D., Bondeau, A., Robustelli, M., and Pinty, B.: Diagnostic assessment of European gross primary production, Global Change Biol., 14, 2349-2364, 2008.

Jungclaus, J. H., Keenlyside, N., Botzet, M., Haak, H., Luo, J. J., Latif, M., Marotzke, J., Mikolajewicz, U., and Roeckner, E.: Ocean circulation and tropical variability in the coupled model ECHAM5/MPI-OM, J. Climate, 19, 3952-3972, 2006.

Karhu, K., Wall, A., Vanhala, P., Liski, J., Esala, M., and Regina, K.: Effects of afforestation and deforestation on boreal soil carbon stocks - Comparison of measured C stocks with Yasso07 model results, Geoderma, 164, 33-45, doi:10.1016/j.geoderma.2011.05.008, 2011.

Koven, C. D., Ringeval, B., Friedlingstein, P., Ciais, P., Cadule, P., Khvorostyanov, D., Krinner, G., and Tarnocai, C.: Permafrost carbon-climate feedbacks accelerate global warming, P. Natl. Acad. Sci., 108, 14769-14774, doi:10.1073/pnas.1103910108, 2011.

Lapola, D. M., Priess, J. A., and Bondeau, A.: Modeling the land requirements and potential productivity of sugarcane and jatropha in Brazil and India using the LPJmL dynamic global vegetation model, Biomass Bioenergy, 33, 1087-1095, 2009.

Leimbach, M., Bauer, N., Baumstark, L., and Edenhofer, O.: Mitigation Costs in a Globalized World: Climate Policy Analysis with REMIND-R, Environ. Model. Assess., 15, 155-173, doi:10.1007/s10666-009-9204-8, 2010a.

Leimbach, M., Bauer, N., Baumstark, L., Luken, M., and Edenhofer, O.: Technological Change and International Trade - Insights from REMIND-R, Energy J., 31, 109-136, $2010 \mathrm{~b}$.

Luyssaert, S., Ciais, P., Piao, S. L., Schulze, E.-D., Jung, M., Zaehle, S., Schelhaas, M. J., Reichstein, M., Churkina, G., Papale, D., Abril, G., Beer, C., Grace, J., Loustau, D., Matteucci, G., Magnani, F., Nabuurs, G. J., Verbeeck, H., Sulkava, M., Van Der WERF, G. R., Janssens, I. A., and Members of the CARBOEUROPE-IP Synthesis Team: The European carbon balance, Part 3: forests, Global Change Biol., 16, 1429-1450, doi:10.1111/j.1365-2486.2009.02056.x, 2010.

Magne, B., Kypreos, S., and Turton, H.: Technology Options for Low Stabilization Pathways with MERGE, Energy J., 31, 83$107,2010$.

Matthews, H. D., Gillett, N. P., Stott, P. A., and Zickfeld, K.: The proportionality of global warming to cumulative carbon emissions, Nature, 459, 829-832, doi:10.1038/nature08047, 2009.

Matthews, H. D., Weaver, A. J., Eby, M., and Meissner, K. J.: Radiative forcing of climate by historical land cover change, Geophys. Res. Lett., 30, 1055, doi:10.1029/2002GL016098, 2003.

Meehl, G. A., Covey, C., Taylor, K. E., Delworth, T., Stouffer, R. J., Latif, M., McAvaney, B., and Mitchell, J. F. B.: The WCRP CMIP3 Multimodel Dataset: A New Era in Climate Change Research, B. Am. Meteorol. Soc., 88, 1383-1394, doi:10.1175/BAMS-88-9-1383, 2007.
Melillo, J. M., McGuire, A. D., Kicklighter, D. W., Moore, B., Vorosmarty, C. J., and Schloss, A. L.: Global climate change and terrestrial net primary production, Nature, 363, 234-240, 1993.

Melillo, J. M., Reilly, J. M., Kicklighter, D. W., Gurgel, A. C., Cronin, T. W., Paltsev, S., Felzer, B. S., Wang, X., Sokolov, A. P., and Schlosser, C. A.: Indirect Emissions from Biofuels: How Important?, Science, 326, 1397-1399, doi:10.1126/science.1180251, 2009.

Michalek, J. L., French, N. H. F., Kasischke, E. S., Johnson, R. D., and Colwell, J. E.: Using Landsat TM data to estimate carbon release from burned biomass in an Alaskan spruce forest complex, Int. J. Remote Sens., 21, 323-338, doi:10.1080/014311600210858, 2000.

Murty, D., Kirschbaum, M. U. F., Mcmurtrie, R. E., and Mcgilvray, H.: Does conversion of forest to agricultural land change soil carbon and nitrogen? a review of the literature, Global Change Biol., 8, 105-123, doi:10.1046/j.1354-1013.2001.00459.x, 2002.

Myers-Smith, I. H., McGuire, A. D., Harden, J. W., and Chapin, F. S.: Influence of disturbance on carbon exchange in a permafrost collapse and adjacent burned forest, J. Geophys. Res., 112, G04017, doi:10.1029/2007JG000423, 2007.

Nakicenovic, N., Alcamo, J., Davis, G., de Vries, B., Fenhann, J., Gaffin, S., Gregory, K., Grubler, A., Jung, T. Y., and Kram, T.: Special report on emissions scenarios: a special report of Working Group III of the Intergovernmental Panel on Climate Change, Pacific Northwest National Laboratory, Richland, WA, USA, Environmental Molecular Sciences Laboratory USA, 2000.

Nobre, C., Dias, M. A. S., Culf, A., Polcher, J., Gash, J., Marengo, J., and Avissar, R.: The Amazonian climate, in: Vegetation, Water, Humans and the Climate: A New Perspective on an Interactive System, edited by: Kabat, P., Claussen, M., Dirmeyer, P., Gash, J., de Guenni, L., Meybeck, M., Pielke Sr., R., Vörösmarty, C., Hutjes, R., and Lütkemeier, S., Springer-Verlag, Berlin, Heidelberg, 79-92, 2004.

Norby, R. J., DeLucia, E. H., Gielen, B., Calfapietra, C., Giardina, C. P., King, J. S., Ledford, J., McCarthy, H. R., Moore, D. J. P., Ceulemans, R., Angelis, P. D., Finzi, A. C., Karnosky, D. F., Kubiske, M. E., Lukac, M., Pregitzer, K. S., Scarascia-Mugnozza, G. E., Schlesinger, W. H. and Oren, R.: Forest response to elevated $\mathrm{CO}_{2}$ is conserved across a broad range of productivity, P. Natl. Acad. Sci. USA, 102, 18052, doi:10.1073/pnas.0509478102, 2005.

Oren, R., Ellsworth, D. S., Johnsen, K. H., Phillips, N., Ewers, B. E., Maier, C., Schafer, K. V. R., McCarthy, H., Hendrey, G., and McNulty, S. G.: Soil fertility limits carbon sequestration by forest ecosystems in a CO2-enriched atmosphere, Nature, 411, 469472, 2001.

Pan, Y., Birdsey, R. A., Fang, J., Houghton, R., Kauppi, P. E., Kurz, W. A., Phillips, O. L., Shvidenko, A., Lewis, S. L., Canadell, J. G., Ciais, P., Jackson, R. B., Pacala, S. W., McGuire, A. D., Piao, S., Rautiainen, A., Sitch, S., and Hayes, D.: A Large and Persistent Carbon Sink in the World's Forests, Science, 333, 988993, doi:10.1126/science.1201609, 2011.

Portmann, F. T., Siebert, S., and Döll, P.: MIRCA2000-Global monthly irrigated and rainfed crop areas around the year 2000: A new high-resolution data set for agricultural and hydrological modeling, Global Biogeochem. Cy., 24, GB1011, doi:10.1029/2008GB003435, 2010. 
Post, W. M. and Kwon, K. C.: Soil carbon sequestration and landuse change: processes and potential, Global Change Biol., 6, 317-327, doi:10.1046/j.1365-2486.2000.00308.x, 2000.

Prentice, I. C., Farquhar, G. D., Fasham, M. J. R., Goulden, M. L., Heimann, M., Kheshi, H. S., Quere, L., Scholes, R. J., Wallace, D. W. R., Archer, D., Ashmore, M. R., Aumont, O., Baker, D., Battle, M., Bender, M., Bopp, L. P., Bousquet, P., Caldeira, K., Ciais, P., Cramer, W., Dentener, F., Enting, I. G., Field, C. B., Holland, E. A., Houghton, R. A., House, J. I., Ishida, A., Jain, A. K., Janssens, I., Joos, F., Kaminski, T., Keeling, C. D., Kicklighter, D. W., Kohfeld, K. E., Knorr, W., Law, R., Lenton, T., Lindsay, K., Maier-Reimer, E., Manning, A., Matear, R. J., McGuire, A. D., Melillo, J. M., Meyer, R., Mund, M., Orr, J. C., Piper, S., Plattner, K., Rayner, P. J., Sitch, S., Slater, R., Taguchi, S., Tans, P. P., Tian, H. Q., Weirig, M. F., Whorf, T., and Yool, A.: The carbon cycle and atmospheric carbon dioxide, in: Climate change 2001: the scientific basis: contribution of Working Group I to the Third Assessment Report of the Intergouvernmental Panel on Climate Change, edited by: Houghton, J. T., available from: http://ir.anet.ua.ac.be/irua/handle/10067/ 381670151162165141 last access: 18 February 2013, Cambridge University Press, Cambridge, 183-237, 2001.

Raddatz, T., Reick, C., Knorr, W., Kattge, J., Roeckner, E., Schnur, R., Schnitzler, K.-G., Wetzel, P., and Jungclaus, J.: Will the tropical land biosphere dominate the climate-carbon cycle feedback during the twenty-first century?, Clim. Dynam., 29, 565-574, doi:10.1007/s00382-007-0247-8, 2007.

Reed, T.: Fuel densities, available from: http://web.archive.org/web/ 20100110042311/http://www.woodgas.com/fuel_densities.htm (last access: 22 November 2012), 2010.

Reich, P. B., Hobbie, S. E., Lee, T., Ellsworth, D. S., West, J. B., Tilman, D., Knops, J. M. H., Naeem, S., and Trost, J.: Nitrogen limitation constrains sustainability of ecosystem response to $\mathrm{CO}_{2}$, Nature, 440, 922-925, doi:10.1038/nature04486, 2006.

Robinson, D. A. and Kukla, G.: Albedo of a Dissipating Snow Cover, J. Appl. Meteorol., 23, 1626-1634, doi:10.1175/15200450(1984)023<1626:AOADSC > 2.0.CO;2, 1984

Roesch, A. and Roeckner, E.: Assessment of Snow Cover and Surface Albedo in the ECHAM5 General Circulation Model, J. Climate, 19, 3828-3843, doi:10.1175/JCLI3825.1, 2006.

Rojstaczer, S.: Human Appropriation of Photosynthesis Products, Science, 294, 2549-2552, doi:10.1126/science.1064375, 2001.

Schaefer, K., Zhang, T., Bruhwiler, L., and Barrett, A. P.: Amount and timing of permafrost carbon release in response to climate warming, Tellus B, 63, 165-180, doi:10.1111/j.16000889.2011.00527.x, 2011.

Schmer, M. R., Vogel, K. P., Mitchell, R. B., and Perrin, R. K.: Net energy of cellulosic ethanol from switchgrass, P. Natl. Acad. Sci., 105, 464-469, 2008.
Schneider von Deimling, T., Meinshausen, M., Levermann, A., Huber, V., Frieler, K., Lawrence, D. M., and Brovkin, V.: Estimating the near-surface permafrost-carbon feedback on global warming, Biogeosciences, 9, 649-665, doi:10.5194/bg-9-649-2012, 2012.

Searchinger, T., Heimlich, R., Houghton, R. A., Dong, F., Elobeid, A., Fabiosa, J., Tokgoz, S., Hayes, D., and Yu, T.-H.: Use of U.S. Croplands for Biofuels Increases Greenhouse Gases Through Emissions from Land-Use Change, Science, 319, 1238 1240, doi:10.1126/science.1151861, 2008.

Sitch, S., Smith, B., Prentice, I. C., Arneth, A., Bondeau, A., Cramer, W., Kaplan, J. O., Levis, S., Lucht, W., Sykes, M. T., Thonicke, K., and Venevsky, S.: Evaluation of ecosystem dynamics, plant geography and terrestrial carbon cycling in the LPJ dynamic global vegetation model, Global Change Biol., 9, 161185, doi:10.1046/j.1365-2486.2003.00569.x, 2003.

Smith, R. S., Shiel, R. S., Millward, D., and Corkhill, P.: The interactive effects of management on the productivity and plant community structure of an upland meadow: an 8-year field trial, J. Appl. Ecol., 37, 1029-1043, doi:10.1046/j.13652664.2000.00566.x, 2000.

Solomon, S., Qin, D., Manning, M., Alley, R., Berntsen, T., Bindoff, N., Chen, Z., Chidthaisong, A., Gregory, J., and Hegerl, G.: Technical summary, in: Climate Change 2007: The Physical Science Basis, Contribution of Working Group I to the Fourth Assessment Report of the Intergovernmental Panel on Climate Change, edited by: Solomon, S., Quin, D., Manning, M., Chen, Z., Marquis, M., Averyt, K. B., Tignor, M., and Miller, H. L., Cambridge University Press, Cambridge, UK and New York, NY, USA, 2007.

Stevens, B., Giorgetta, M., Esch, M., Mauritsen, T., Crueger, T., Rast, S., Salzmann, M., Schmidt, H., Bader, J., Block, K., Brokopf, R., Fast, I., Kinne, S., Kornblueh, L., Lohmann, U., Pincus, R., Reichler, T., and Roeckner, E.: The Atmospheric Component of the MPI-M Earth System Model: ECHAM6, J. Adv. Model. Earth., Syst., accepted, 2012.

Thompson, S. L., Govindasamy, B., Mirin, A., Caldeira, K., Delire, C., Milovich, J., Wickett, M., and Erickson, D.: Quantifying the effects of $\mathrm{CO}_{2}$-fertilized vegetation on future global climate and carbon dynamics, Geophys. Res. Lett., 31, L23211, doi:10.1029/2004GL021239, 2004.

Waha, K., van Bussel, L. G. J., Müller, C., and Bondeau, A.: Climate-driven simulation of global crop sowing dates, Global Ecol. Biogeogr., 21, 247-259, doi:10.1111/j.14668238.2011.00678.x, 2012.

Witt, C., Cassman, K., Olk, D., Biker, U., Liboon, S., Samson, M., and Ottow, J.: Crop rotation and residue management effects on carbon sequestration, nitrogen cycling and productivity of irrigated rice systems, Plant Soil, 225, 263-278, 2000.

Zimov, S. A., Schuur, E. A. G., and Chapin, F. S.: Permafrost and the Global Carbon Budget, Science, 312, 1612-1613, doi:10.1126/science.1128908, 2006. 